\title{
Production of Extracellular Protease by a Brazilian Strain of Beauveria bassiana Reactivated on Coffee Berry Borer, Hypothenemus hampei
}

\author{
Eliana Tiemi Ito, Geni Varéa-Pereira ${ }^{1} *$, Dalva Tomoe Miyagui ${ }^{1}$, Maria Helena Pimenta \\ Pinotti $^{1}$ and Pedro Manoel Oliveira Janeiro Neves ${ }^{2}$ \\ ${ }^{I}$ Departamento de Bioquímica e Biotecnologia; ${ }^{2}$ Departamento de Agronomia; Universidade Estadual de Londrina; \\ Campus Universitário; C. P. 6001; 86051-990; Londrina - PR - Brasil
}

\begin{abstract}
Studies were carried out on extracellular protease production by Beauveria bassiana CG432 in liquid medium containing glucose and yeast extract. B. Bassiana presented active growth after lag period of 24 h., produced $80 \%$ of the total of the extracellular protease activity in $48 \mathrm{~h}$ which was maximum on the $5^{\text {th }}$ culture day. The extracellular protease presented optimum activity at $60^{\circ} \mathrm{C}$, was stable up to $1 \mathrm{M} \mathrm{Cl}$, maintained the stability during 15 day at $4^{\circ} \mathrm{C}$ and $-18^{\circ} \mathrm{C}$, but was not stable if frozen repeatedly.
\end{abstract}

Key words: Protease activity, Beauveria bassiana, enzyme stability

\section{INTRODUCTION}

The entomopathogenic fungus Beauveria bassiana is commonly isolated from dead insects in the environment (Boucias and Pendland, 1998; Cottrell and Shapiro-Ilan, 2003) and its spores are frequently used as biological control agent against pest infestation in agriculture (MacLeod, 1954; Furlong and Pell, 2001). During multiplication on the insect, the conidia produce different virulence factors, identified as extracellular enzymes, especially proteases characterized as chymotrypsin-like serine proteinases with activity on casein, hide protein azure (HPA), azocoll, elastin Congo Red and collagen substrates (Chrzanowska et al., 2001), chitinases (Samsinakova et al., 1971; St-Leger et al., 1986) and lipases (Giraldo-Cardozo et al., 2001).
The production of extracellular enzymes was related to the infection process of the insects because it allowed the penetration of the germ tube across the cuticle which is formed by nearly $70 \%$ of proteins (Hepburn, 1985), chitin and lipids (Bidochka and Khachatourians, 1992), and the growth of the fungus through the use of hemolymph nutrients (Shimizu et al., 1993). The entomopathogenic fungus can diversify the production of virulence factors in response to the different insects (Moino et al., 1998). Inducer substrates have been tested in order to increase the protein content and to release the extracellular proteases to make easier the studies on kinetic activity and structure and to correlate with virulence levels of the fungal strain in bioassays on insects. Neves and Hirose (2005) observed that the Brazilian B. bassiana strain CG432 bioassayed on coffee berry borer, Hypothenemus hampei,

${ }^{*}$ Author for correspondence 
presented better conidia production and more than $70 \%$ of mortality, with $10^{8}$ conidia $/ \mathrm{mL}$ concentration among 61 Brazilian strains when reactivated on the same insect. Previous studies showed that extracelullar proteases produced by this strain were active at $\mathrm{pH} 4.5,7.0$ and 9.5, suggesting the production at least three different type of proteases (Stürmer et al., 2003/2004).

There are many papers about protease production and their characteristics, but more information is necessary about $B$. bassiana strains adapted at Brazilian conditions. Thus, the objective of this study was to determine the culture time for the maximum production of extracellular proteases by B. bassiana CG432 reactivated on coffee berry borer and the effect of some reaction and storage conditions on the activity and stability of these enzymes.

\section{MATERIALS AND METHODS}

\section{Fungal strain}

B. bassiana CG432 was isolated from adult insects of the family Membracidae (Homoptera), Rio Grande do Norte State, northeast, Brazil, supplied to the Entomopathogen Bank in the Department of Agronomy at Londrina State University by the Brazilian Corporation for Agricultural Research EMBRAPA/Cenargen.

\section{Conidium reactivation}

The fungus conidia was maintained in Petri dishes containing the solid culture medium for $B$. bassiana: $20 \mathrm{~g}$ agar, $10 \mathrm{~g}$ anhydrous $\mathrm{D}$-glucose, $5 \mathrm{~g}$ yeast extract, $\quad 1.58 \mathrm{~g} \quad \mathrm{NaNO}_{3}, \quad 1.05 \mathrm{~g}$ $\mathrm{Na}_{2} \mathrm{HPO}_{4} .7 \mathrm{H}_{2} \mathrm{O}, 1 \mathrm{~g} \mathrm{KCl} ; 0.6 \mathrm{~g} \mathrm{MgSO}_{4} .7 \mathrm{H}_{2} \mathrm{O}$ and $0.36 \mathrm{~g} \mathrm{KH}_{2} \mathrm{PO}_{4}$, distilled water to one liter (Alves, 1998 ), at $25^{\circ} \mathrm{C}, 12 \mathrm{~h}$ photophase, for ten days. Media produced conidia were sprayed on $H$. hampei alive adults previously treated with $0.5 \%$ sodium hypochlorite solution placed on Petri dishes and incubated at $25^{\circ} \mathrm{C}$ until insect death. Newly emerged conidia from the insect were subcultured not more than four times, at ten days intervals in solid culture medium and used to prepare the reactivated inoculum suspension containing $10^{8}$ conidia/mL (Neves and Hirose, 2005).

\section{Fungal growth conditions}

The fungus was cultivated at $28^{\circ} \mathrm{C}, 150 \mathrm{rpm}$ during for nine days in $250 \mathrm{~mL}$ erlenmeyers flacks, with $100 \mathrm{~mL}$ of liquid culture medium (as above culture medium) without agar with $1 \%$ of the suspension of $10^{8}$ conidia/mL as the inoculum, in duplicate. One un-inoculated culture medium was used as control. At $24 \mathrm{~h}$, a group of the three flacks (duplicate and control) was filtrated through previously weighed Whatman № 1 filter papers and the filtrate, called crude extract (CE), was dialysed against $5 \mathrm{mM}$ phosphate buffer $\mathrm{pH} 7$ at $4^{\circ} \mathrm{C}$, served as the enzyme source for determination of the extracellular protease activity and the soluble protein content.

\section{Biomass determination}

Biomass was determined from the residue material on the filter paper. The biomass obtained from the $1^{\text {st }}$ to the $9^{\text {th }}$ day of cultivation was washed with two aliquots $(50 \mathrm{~mL}$ each) of distilled water and dried at $70^{\circ} \mathrm{C}$ until constant weight.

\section{Extracellular protease assay}

Extracellular protease was determinated (Ito, 2003), using 200 $\mu$ l aliquots of CEs obtained from the first to the ninth day of culture were incubated at $37^{\circ} \mathrm{C}$ for 30 minutes with $100 \mu 1$ of the $50 \mathrm{mM}$ phosphate buffer $\mathrm{pH} 7$ and $250 \mu \mathrm{L}$ bovine serum albumin $5 \mathrm{mg} / \mathrm{mL}$ dissolved in the same buffer. The reaction was interrupted with $250 \mu \mathrm{L} 10 \%$ TCA and centrifuged at $1100 \mathrm{~g}$ for 15 minutes The protease activity was considered as the absorbance lecture at $650 \mathrm{~nm}$ corresponding to the released soluble peptide content of the supernatant (Hartree, 1972). Each 0.1 increased in absorbance was considered as one unity of protease activity.

\section{Effect of temperature and íons $\mathrm{Cl}^{-}$on protease activity}

Temperature and $\mathrm{Cl}^{-}$effect on protease activity was determined using the $\mathrm{CE}$ obtained after 5 days of cultivation in $50 \mathrm{mM}$ phosphate buffer $\mathrm{pH} 7$ at temperatures from 20 to $70^{\circ} \mathrm{C}$. The effect of 0.1 to $1.0 \mathrm{M} \mathrm{NaCl}$ concentration was determinated at $37^{\circ} \mathrm{C}$ in $50 \mathrm{mM}$ acetate, phosphate and Glycine$\mathrm{NaOH}$ buffer at $\mathrm{pH} 4.5,7$ and 9.5, respectively (Stürmer et al., 2003/2004).

\section{Protease stability on storage conditions}

Protease stability was evaluated by determining the protease activity of CE obtained on the $5^{\text {th }}$ 
cultivation day after stay storing at $4^{\circ} \mathrm{C}$ or frozen at $-18^{\circ} \mathrm{C}$ for 30 days. The effect of successive freezing and thawing of the sample was also evaluated 6 times (each 5 days) during the same time period.

\section{RESULTS AND DISCUSSION}

\section{Protease production and fungal growth}

The highest extracellular protease activity by $B$ bassiana CG432 (Fig. 1A) was observed on the $5^{\text {th }}$

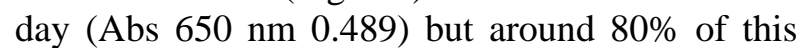
activity was obtained after $2^{\text {nd }}$ day of the cultivation. After the $5^{\text {th }}$ day, there was an abrupt reduction of the activity until the $9^{\text {th }}$ day. Variable time courses of extracellular protease production have been related in literature, reflecting the variability in protease production on different media. The stimulatory effects of a series of 24 nitrogen sources including inorganic, organic nonprotein, proteins and complex natural media on the production of proteases in submerged cultures demonstrated that the maximum amount of protease into the maize meal, yeast extract, ground maize and wheat bran broth was released 3 days after inoculation (Kucera, 1971).
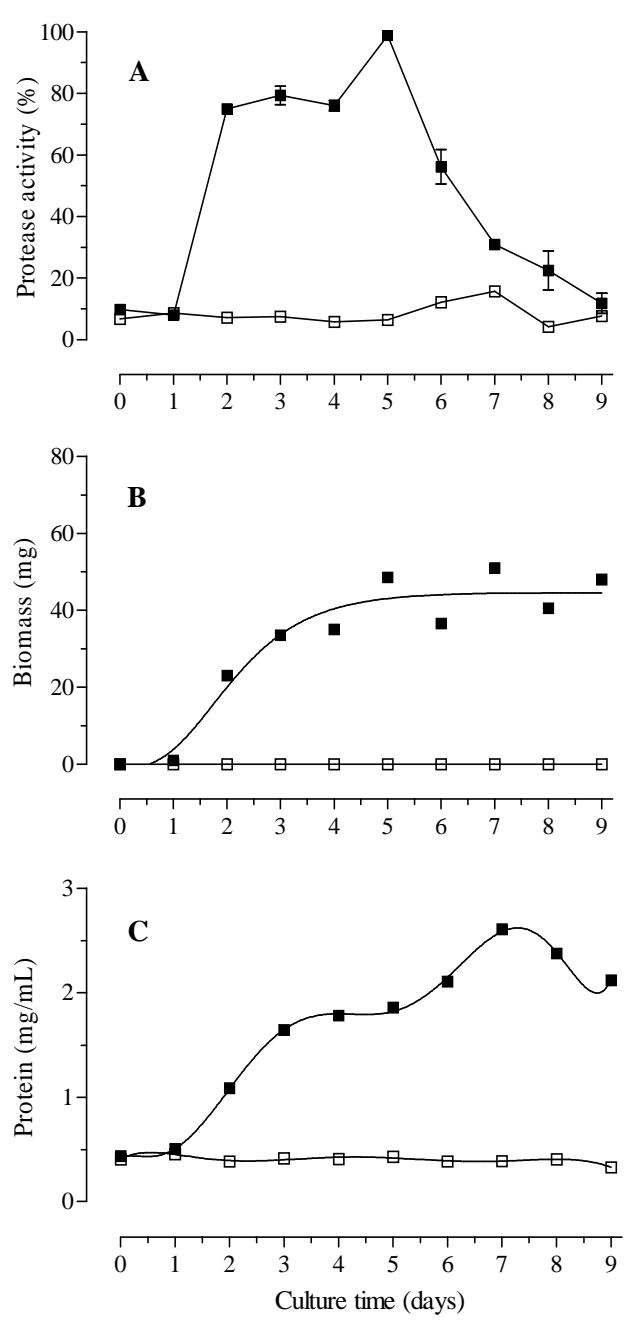

Figure 1 - Growth curve of Beauveria bassiana CG432. Fungi culture (๘); no inoculated medium ( $\square)$. Time course of protease production (A); biomass weight (B); protein concentration (C). 
Others studies that used inducer substrates to produce proteases from $B$. bassiana, stopped the cultures in between $3^{\text {rd }}$ to $6^{\text {th }}$ day of the cultivation as $0.2 \%$ lyophilized porcine blood plasma and $0.5 \%$ ground larval of Apis mellifera with higher release at $3^{\text {rd }}$ day by $B$. Bassiana 278 (Chrzanowska et al., 2001), $1 \%$ gelatin at $3^{\text {rd }}$ and $4^{\text {th }}$ day by $B$ bassiana GK2016 (Bidochka and Khachatourians, 1987 and 1988), 1\% gelatin and casein, at $4^{\text {th }}$ day by $B$. bassiana $11892 \mathrm{~A}$ (Urtz and Rice, 2000), ground migratory grasshopper cuticle, at $5^{\text {th }}$ day by $B$ bassiana GK2016 and GK2018 (Bidochka and Khachatourians, 1990, 1991, 1993), colloidal chitin, at $6^{\text {th }}$ day (Havukkala et al. 1993), and liquid medium with cuticle ground from the own coffee berry borer, Hypothenemus hampei at $5^{\text {th }}$ to $7^{\text {th }}$ days after the inoculation (GiraldoCardozo et al., 2001).

The biomass production (Fig. 1B) and the concentration of soluble protein (Fig. 1C) of the culture medium increased after $2^{\text {nd }}$ day and coincided with $80 \%$ of the total of the extracellular protease production, after a small lag period of 24 $\mathrm{h}$ shorter than obtained by two isolates of $B$. Bassiana (Arcas et al., 1999). These results could be related with the production of complex proteolityc enzymes during the reactivation of the inoculum on coffee berry borer alive, using liquid medium without inducer substrates such as the cuticle (Havukkala et al. 1993; Urtz and Rice,
2000) or extract from insects (Bidochka and Khachatourians, 1990, 1991, 1993; GiraldoCardozo et al., 2001).

The active growth continued until the $5^{\text {th }}$ day when the enzyme was released in the culture medium reaching the maximum extracellular protease activity. After that, the biomass production was stable when the protease release was reduced (Fig. $1 \mathrm{~A}$ and 1B). These results confirmed the importance of the extracellular protease activity on the substrate utilization during the multiplication celular phase of this fungus as related to other microorganisms (Fu-Chu et al., 2004). The concentration of soluble protein of the culture medium was highest on the $7^{\text {th }}$ day probably related with biomass (Fig. 1C).

The previous reactivation of the fungus on insects proposed in this work presented the advantage of less laborious laboratory work to produce the inoculum than to prepare different substrates and less cultivation time, considering that $80 \%$ of the total activity was obtained on $2^{\text {nd }}$ day.

\section{Temperature effect}

The extracellular proteases were more active between 40 and $60^{\circ} \mathrm{C}$ (Fig. 2). This result was better than those by Bidochka and Khachatourians (1987), with optimum temperature between 37 to $42^{\circ} \mathrm{C}$.

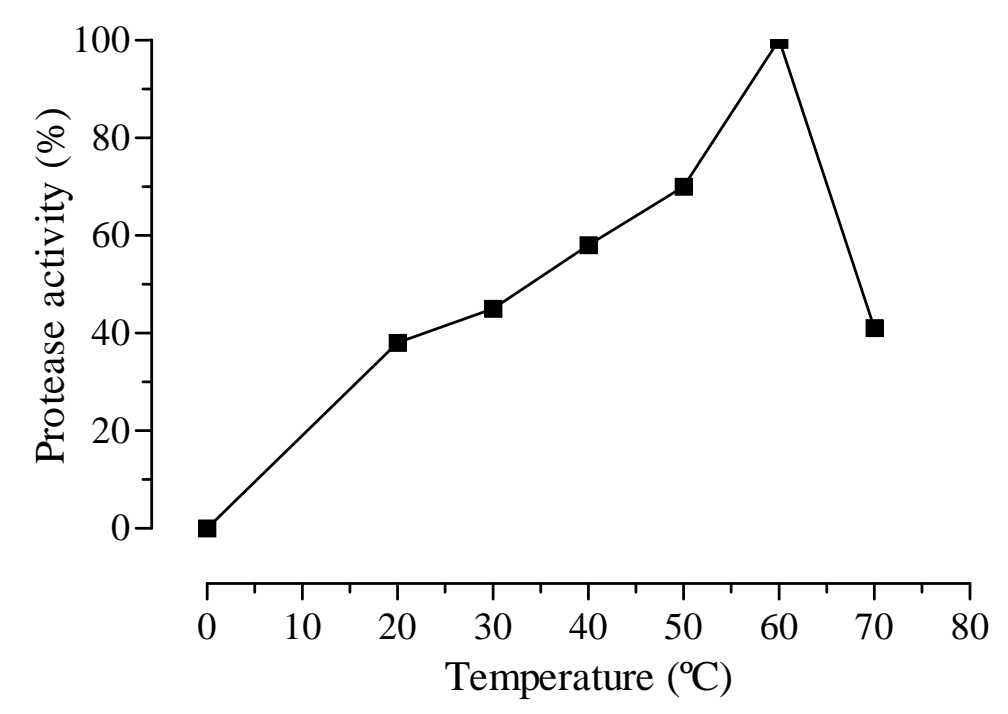

Figure 2 - Effect of the temperature on the extracellular protease activity produced by Beauveria bassiana CG432. 


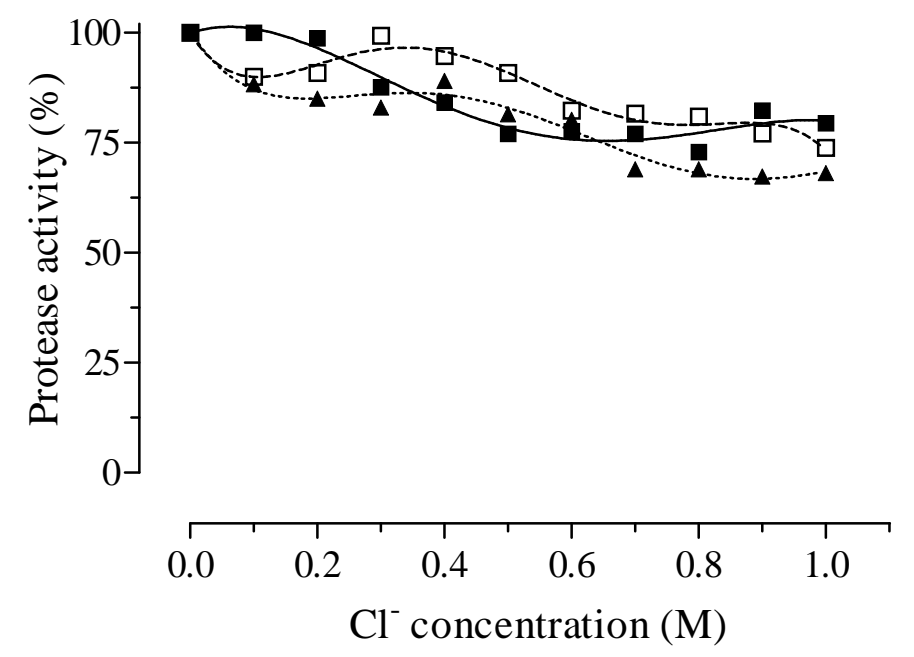

Figure 3 - Effect of chloride ion concentation at pH $4.5(\square), 7.0(\mathbf{\square})$ and $9.5(\boldsymbol{\Delta}) \mathrm{pH}$ on the extracellular protease activity produced by Beauveria bassiana CG432.

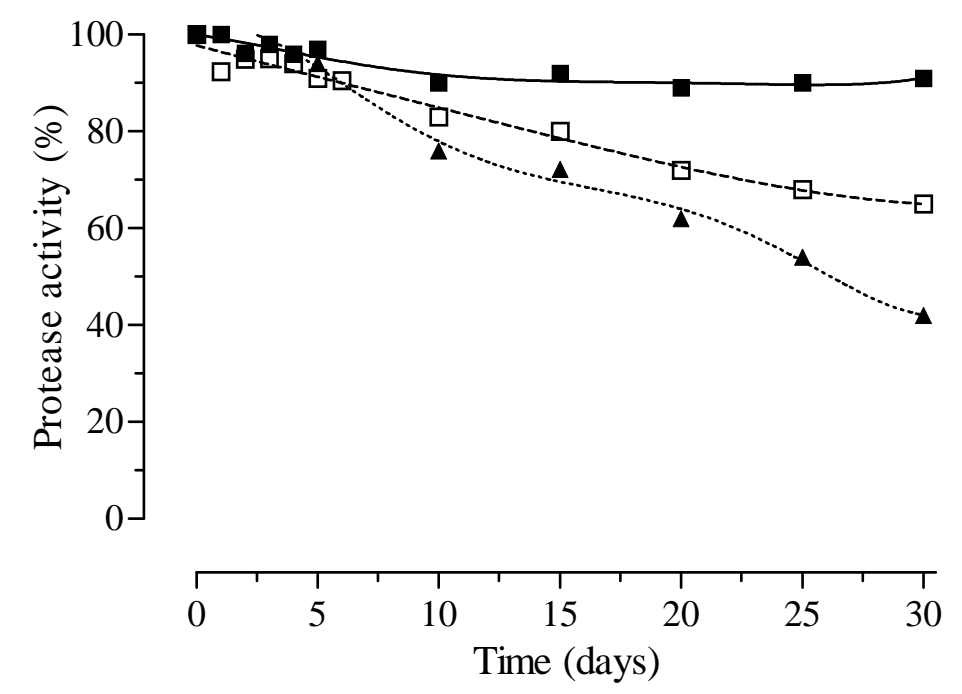

Figure 4 - Stability of extracellular protease produced by Beauveria bassiana CG432 stored at $4^{\circ} \mathrm{C}$ refrigeration (口), $-18^{\circ} \mathrm{C}$ freezing (a) and submitted to repetitive freezing/thawing $(\boldsymbol{\Delta})$.

\section{$\mathrm{Cl}^{-}$ion concentration effect}

The CE proteases remained active when analyzed in increasing concentrations of chloride ions of 0.1 to $1.0 \mathrm{M}$ at $\mathrm{pH} 4.5,7.0$ and 9.5 (Fig. 3). This could be important information, because chloride ions are frequently used on buffer analysis and purification laboratory procedures. 


\section{Protease stability in storage}

It was observed that the proteases maintained above $90 \%$ of their activity up to the $30^{\text {ty }}$ day under freezing and above $80 \%$ until the $15^{\text {th }}$ day under refrigeration. The activity fell down to $50 \%$ at the $5^{\text {th }}$ times of freezing/thawing (Fig. 4). Thus, repetitive freezing of the extracts should be avoided.

At least, the extracellular proteases produced in these conditions presented optimum temperature activity at $60^{\circ} \mathrm{C}$, without interferences from $\mathrm{Cl}^{-}$ion and was stable for many days on refrigeration or freezing conditions. This fact could be very important in purification procedures. Also, proteases produced under same conditions were stable during 10 days at $25^{\circ} \mathrm{C}$ (Stürmer et al., 2003/2004) being too important on insect procedures for bioassay when used as bioinseticide.

\section{ACKNOWLEDGMENTS}

Ito, E. T. whishes to thank Fundação Araucária/Pr and Fundação Coordenação de Aperfeiçoamento de Pessoal de Nível Superior (CAPES) for the fellowship for the Master Course in Biotechnology. The authors acknowledge Pro-Reitoria de Pesquisa e PósGraduação (PROPPG-UEL-number 24698/2003), Fundação Araucária (number213/2003) and Conselho Nacional de Desenvolvimento Científico e Tecnológico (CNPq-number 473595/2003-6) for the financial supports and to $\operatorname{Prof}^{\mathrm{a}} \operatorname{Dr}^{\mathrm{a}}$ Maria Helena Pimenta Pinotti for the English revision.

\section{RESUMO}

A cepa brasileira do fungo entomopatogênico Beauveria bassiana CG432 foi cultivada em meio de cultivo líquido contendo glucose e extrato de levedura a $28^{\circ} \mathrm{C}, 150 \mathrm{rpm}$, durante 9 dias utilizando $1 \%$ de inóculo constituído por $10^{8}$ conídios/mL pré-ativados em insetos vivos de broca-do-café. Avaliou-se diariamente o crescimento do fungo através da quantificação da biomassa e a atividade de proteases extracelulares no filtrado do cultivo pela determinação de peptídeos solúveis liberados pela hidrólise de soro albumina bovina a $37^{\circ} \mathrm{C}$ durante 30 minutos. $\mathrm{O}$ fungo cresceu ativamente após reduzido período lag de 24 horas, produziu $80 \%$ da atividade total de proteases em 48 horas e atingiu produção máxima em 5 dias de cultivo, sem adição de substratos indutores no meio de cultivo. As proteases apresentaram atividade ótima a $60^{\circ} \mathrm{C}$, estabilidade até $1 \mathrm{M}$ de íons cloreto, mantiveram mais de $80 \%$ de atividade durante 15 dias a $4^{\circ} \mathrm{C}$ e $-18^{\circ} \mathrm{C}$, porém foram sensíveis a congelamentos repetitivos.

\section{REFERENCES}

Alves, S. B. (1998), Patologia e Controle Microbiano: vantagens e desvantagens/Técnicas de Laboratório. In: Controle Microbiano de Insetos, 2 ed. FEALQ, Piracicaba, pp. 665.

Arcas, J. A.; Días, B. M. and Lecuona, R. E. (1999), Bioinsecticidal activity of conidia and dry mycelium preparation of two isolates of Beauveria bassiana against the sugarcane borer Diatraea saccharalis. Journal of Biotechnology, 67, 151-158.

Bidochka, M. J. and Khachatourians, G. G. (1992), Growth of the entomopathogenic fungus Beauveria bassiana on cuticular components from the migratory grasshopper Melanoplus sanguinipes. Journal of Invertebrate Pathology, 59, 165-173.

Bidochka, M. J. and Khachatourians, G. G. (1990), Identification of Beauveria bassiana extracellular protease as a virulence factor in pathogenicity toward the migratory grasshopper, Melanoplus sanguinipes. Journal of Invertebrate Pathology, 56, 362-370.

Bidochka, M. J. and Khachatourians, G. G. (1993), Oxalic acid hyperproduction in Beauveria bassiana mutants is related to a utilizable carbon source but not to virulence. Journal Invertebrate Pathology, 62, 5357.

Bidochka, M. J. and Khachatourians, G. G. (1987), Purification and properties of an extracellular protease produced by the entomopathogenic fungus Beauveria bassiana. Applied and Environmental Microbiology, 53: (7), 1679-1684.

Bidochka, M. J. and Khachatourians, G. G. (1988), Regulation of extracellular protease in the entomopathogenic fungus Beauveria bassiana. Experimental Mycology, 12, 161-168.

Bidochka, M. J. and Khachatourians, G. G. (1991), The implication of metabolic acids produced by Beauveria bassiana in pathogenesis of the migratory grasshopper, Melanoplus sanguinipes. Journal of Invertebrate Pathology, 58, 106-117.

Boucias, D. G. and Pendland, J. C. (1998), Principles of Insect Pathology, Kluwer, Boston. 
Chen, Fu-Chu; Shen, Li-Fen and Chak, Kin-Fu. (2004), A facile analytical method for the identification of protease gene profiles from Bacillus thuringiensis strains. Journal of Microbiological Methods, 56, 125132.

Cottrell, T. E. and Shapiro-Ilan, D. I. (2003), Susceptibility of a native and an exotic lady beetle (Coleoptera: Coccinellidae) to Beauveria bassiana. Journal of Invertebrate Pathology, 84, 137-144.

Chrzanowska, J.; Banas, J.; and Kolaczkowska, M. (2001), Purification and characterization of Beauveria bassiana proteinases. Acta Biotechnology, 21: (1), 73-81.

FURLONG, M. J. and PELL, J. K. (2001), Horizontal transmission of entomopathogenic fungi by the diamondback moth. Biological Control, 22, 288-299.

Giraldo-Cardozo, E. M.; López-F, Y.; Delgado-B., F. and Vélez-A, P. E. (2001), Actividad lipolítica y proteolítica de Beauveria bassiana y Metarhizium anisopliae y su relación con la patogenicidad sobre Hypothenemus hampei (Coleoptera: Scolytidae). Revista Colombiana de Entomología, 27: (1-2), 6165.

Hartree, E. F. (1972), Determination of Protein: A modification of the Lowry method that gives a linear photometric response. Analytical Biochemistry, 48, $422-427$.

Havukkala, I.; Mitamura, C.; Hara, S.; Hirayae, K.; Nishizawa, Y. and Hibi, T. (1993), Induction and purification of Beauveria bassiana chitinolytic enzymes, Journal of Invertebrate Pathology, 61, 97102.

Hepburn, H. R. (1985), Structure of the Integument. In: Comprehensive Insect Physiology, Biochemistry and Pharmacology, G. A. Kerkut and L. I.Gilbert, Eds., 3, Pergamon, Oxford, pp. 1-58.

Ito, E.T. (2003), Estabilidade e perfil de produção de proteases pelo fungo entomopatogênico Beauveria bassiana (BALS.) VUILL. Monografia (Especialização em Bioquímica Aplicada), Universidade Estadual de Londrina, Londrina, Paraná, Brasil.
Kucera, M. (1971), Toxins of the entomophagous fungus Beauveria bassiana. II. Effect of nitrogen sources on formation of the toxic protease in submerged culture. Journal of Invertebrate Pathology, 17, 211-215.

Leopold, J. and Samsinakova, A. (1970), Quantitative estimation of chitinase and several other enzymes in the fungus Beauveria bassiana. Journal of Invertebrate Pathology, 15, 34-42.

MacLeod, D. M. (1954), Investigations on the genera Beauveria Vuill. and Tritirachium Limber. Canadian Journal of Botany, 32, 818-890.

Moino Jr., A.; Alves, S. B. And Pereira, R. M. (1998), Efficacy of Beauveria bassiana (Balsamo) Vuillemin isolates for control of stored-grain pests. Journal of Applied Entomology, 122, 301-305.

Neves, P. M. O. J and Hirose, E. (2005), Seleção de isolados de Beauveria bassiana para o controle biológico da broca-do-café, Hypothenemus hampei (Ferrari) (Coleoptera: Scolytidae). Neotropical Entomology, 34: (1), 77-82.

Samsinakova, A.; Misikova, S. and Leopold, J. (1971), Action of enzymatic systems of Beauveria bassiana on the cuticle of the greater wax moth larvae (Galleria mellonella). Journal of Invertebrate Pathology, 18, 322-330.

Shimizu, S.; Tsuchitani, Y. and Matsumoto, T. (1993), Production of an extracellular protease by Beauveria bassiana in the haemolymph of the silkworm, Bombyx mori, Letters in Applied Microbiology, 16, 291-294.

St-Leger, R. J.; Charnley, A. K. And Cooper, R. M. (1986), Cuticle-degrading enzymes of entomopathogenic fungi: Synthesis in culture on cuticle. Journal of Invertebrate Pathology, 48, 85-95.

Stürmer, A. T.; Ito, E. T. and Varéa-Pereira, G. (2003/2004), Estabilidade de proteases produzidas pelo fungo entomopatogênico Beauveria bassiana. Revista UNOPAR Científica - Ciências Biológicas e da Saúde, 5/6, 13-19.

Urtz, B. E. and Rice, W. C. (2000), Purification and characterization of a novel extracellular protease from Beauveria bassiana. Mycological Research., 104: (2), 180-186. 
PÁGINA

EM

BRANCO 